\title{
Unconventional Stoichiometries of Na-O Compounds at High Pressures
}

\author{
Lihua Yang ${ }^{1,2}$, Yukai Zhang ${ }^{1}$, Yanli Chen ${ }^{1, * \mathbb{D}}$, Xin Zhong ${ }^{1}$, Dandan Wang ${ }^{1}$, Jihui Lang ${ }^{1}$, Xin Qu ${ }^{1, * \mathbb{D}}$ \\ and Jinghai Yang ${ }^{1, *}$
}

check for updates

Citation: Yang, L.; Zhang, Y.; Chen, Y.; Zhong, X.; Wang, D.; Lang, J.; Qu, X.; Yang, J. Unconventional Stoichiometries of Na-O Compounds at High Pressures. Materials 2021, 14 , 7650. https://doi.org/10.3390/ ma14247650

\section{Academic Editors:}

Dimitra Vernardou, Davide Ceresoli and Aivaras Kareiva

Received: 7 October 2021

Accepted: 10 December 2021

Published: 12 December 2021

Publisher's Note: MDPI stays neutral with regard to jurisdictional claims in published maps and institutional affiliations.

Copyright: (c) 2021 by the authors. Licensee MDPI, Basel, Switzerland. This article is an open access article distributed under the terms and conditions of the Creative Commons Attribution (CC BY) license (https:// creativecommons.org/licenses/by/ $4.0 /)$.
1 Key Laboratory of Functional Materials Physics and Chemistry of the Ministry of Education, National Demonstration Center for Experimental Physics Education, College of Physics, Jilin Normal University, Siping 136000, China; yanglh@jlnu.edu.cn (L.Y.); Lance19950815@163.com (Y.Z.); zhongxin@calypso.cn (X.Z.); mila880227@126.com (D.W.); jhlang@jlnu.edu.cn (J.L.)

2 State Key Laboratory of Integrated Optoelectronics, College of Materials Science and Engineering, Jilin University, Changchun 130012, China

* Correspondence: ylchen@jlnu.edu.cn (Y.C.); quxin515@163.com (X.Q.); jhyang1@jlnu.edu.cn (J.Y.)

\begin{abstract}
It has been realized that the stoichiometries of compounds may change under high pressure, which is crucial in the discovery of novel materials. This work uses systematic structure exploration and first-principles calculations to consider the stability of different stoichiometries of $\mathrm{Na}-\mathrm{O}$ compounds with respect to pressure and, thus, construct a high-pressure stability field and convex hull diagram. Four previously unknown stoichiometries $\left(\mathrm{NaO}_{5}, \mathrm{NaO}_{4}, \mathrm{Na}_{4} \mathrm{O}\right.$, and $\left.\mathrm{Na}_{3} \mathrm{O}\right)$ are predicted to be thermodynamically stable. Four new phases (P2/m and $C m c 2_{1} \mathrm{NaO}_{2}$ and $I m m m$ and $C 2 / m \mathrm{NaO}_{3}$ ) of known stoichiometries are also found. The O-rich stoichiometries show the remarkable features of all the $\mathrm{O}$ atoms existing as quasimolecular $\mathrm{O}_{2}$ units and being metallic. Calculations of the $\mathrm{O}-\mathrm{O}$ bond lengths and Bader charges are used to explore the electronic properties and chemical bonding of the O-rich compounds. The Na-rich compounds stabilized at extreme pressures ( $\mathrm{P}>200 \mathrm{GPa})$ are electrides with strong interstitial electron localization. The $\mathrm{C} 2 / \mathrm{c}$ phase of $\mathrm{Na}_{3} \mathrm{O}$ is found to be a zerodimensional electride with an insulating character. The $C m c a$ phase of $\mathrm{Na}_{4} \mathrm{O}$ is a one-dimensional metallic electride. These findings of new compounds with unusual chemistry might stimulate future experimental and theoretical investigations.
\end{abstract}

Keywords: high pressure; structure prediction; electride

\section{Introduction}

Sodium and oxygen are among the most abundant elements in the solar system [1]. Sodium readily interacts with oxygen, typically producing $\mathrm{Na}_{2} \mathrm{O}$, in which $\mathrm{Na}$ and $\mathrm{O}$ have oxidation states +1 and -2 , respectively. Sodium can also react with oxygen to form sodium peroxide $\left(\mathrm{Na}_{2} \mathrm{O}_{2}\right)$, sodium superoxide $\left(\mathrm{NaO}_{2}\right)$, and sodium ozonide $\left(\mathrm{NaO}_{3}\right)$, in which peroxide $\left(\mathrm{O}_{2}{ }^{2-}\right)$, superoxide $\left(\mathrm{O}_{2}{ }^{-}\right)$, and ozonide $\left(\mathrm{O}_{3}{ }^{-}\right)$groups, respectively, act as anions [2]. Na-O compounds have broad applications, e.g., as oxidizing agents, oxygen sources, and magnetic materials [3,4]. They are also the discharge products of Na-air batteries [5-7]. Therefore, obtaining an in-depth understanding of the structure and properties of $\mathrm{Na}-\mathrm{O}$ compounds under different external conditions is of fundamental importance. The high-pressure structures and properties of these $\mathrm{Na}-\mathrm{O}$ compounds have been widely investigated both experimentally and theoretically at $50 \mathrm{GPa}$ [5,8-12].

Pressure is a powerful tool to rearrange electrons, modify chemical bonding, and create new exotic materials [13-18]. The rapid development of structure prediction has facilitated the discovery of pressure-stabilized compounds with unusual stoichiometries; examples include S-H [19-21], $\mathrm{Na}-\mathrm{Cl}$ [22], Xe-O/Fe [23,24], and $\mathrm{La}-\mathrm{H}[25,26]$. Some of them have subsequently been successfully synthesized [27,28]. Alkali metal sodium is a typical element showing an intriguing structure and properties under compression. 
For instance, the observed anomalous insulativity in the first high-pressure electride $\mathrm{Na}-\mathrm{hP} 4$ [29] led to a research boom on high-pressure electrides. Similarly, many novel stoichiometries and chemical properties have been found in the $\mathrm{Na}-\mathrm{Cl}$ system under high pressure [22]; $\mathrm{Na}_{3} \mathrm{Cl}, \mathrm{Na}_{2} \mathrm{Cl}, \mathrm{Na}_{3} \mathrm{Cl}_{2}, \mathrm{NaCl}_{3}$, and $\mathrm{NaCl}_{7}$ are theoretically stable and show unusual bonding and electronic properties. Remarkably, the most inert element, $\mathrm{He}$, has shown the ability to form a compound, $\mathrm{Na}_{2} \mathrm{He}$, at pressure greater than $113 \mathrm{GPa}$ [30]. Oxygen also shows intriguing structures and oxidation states under compression. It is also the third most abundant element in the Earth's crust; hence, understanding its behavior under extreme pressures provides important insights into planetary interiors and oxidation chemistry [2]. A recent experimental and theoretical study found an unconventional pressure-stabilized divalent ozonide $\mathrm{CaO}_{3}$ crystal with intriguing bonding; its existence has profound geological implications [31]. Recent discoveries of iron oxides with unusual oxidation states $\left(\mathrm{FeO}_{2}\right.$ [32], $\mathrm{Fe}_{2} \mathrm{O}_{3}$ [33], and $\mathrm{Fe}_{5} \mathrm{O}_{6}$ [34]) are also notable.

Considering the intriguing stoichiometries, structures, and electronic properties of $\mathrm{Na}-$ and O-related substances under compression, binary compounds formed by $\mathrm{Na}$ and $\mathrm{O}$ atoms show relatively simple high-pressure behaviors. Thus, one might wonder whether new phenomenon (new stoichiometries, structures, and electronic properties) can be observed for $\mathrm{Na}-\mathrm{O}$ systems at elevated pressures. Thus, this work reports a systematic search for crystal structures of different $\mathrm{Na}-\mathrm{O}$ stoichiometries at pressures of 50-300 GPa with the aim of finding compounds unavailable under ambient conditions. Four new stoichiometries are predicted to be thermodynamically stable: $\mathrm{NaO}_{5}, \mathrm{NaO}_{4}, \mathrm{Na}_{4} \mathrm{O}$, and $\mathrm{Na}_{3} \mathrm{O}$. Four new phases $\left(P 2 / m\right.$ and $\mathrm{Cmc}_{1} \mathrm{NaO}_{2}$ and $I m m m$ and $\left.\mathrm{C} 2 / m \mathrm{NaO}_{3}\right)$ of known stoichiometries are also found. The O-rich stoichiometries show the remarkable feature of having all the $\mathrm{O}$ atoms existing as quasimolecular $\mathrm{O}_{2}$ units and being metallic. Calculations of the $\mathrm{O}-\mathrm{O}$ bond lengths and Bader charges are used to explore the electronic properties and chemical bonding of the O-rich compounds. The Na-rich $\mathrm{Na}-\mathrm{O}$ compounds stabilized at extreme pressures $(\mathrm{P}>200 \mathrm{GPa})$ are electrides with strong interstitial electron localization. The $\mathrm{C} 2 / \mathrm{c}$ phase of $\mathrm{Na}_{3} \mathrm{O}$ is found to be a zero-dimensional (0D) electride with an insulating character. The $\mathrm{Cmca}$ phase of $\mathrm{Na}_{4} \mathrm{O}$ is a one-dimensional (1D) metallic electride.

\section{Computational Methods and Details}

Structure searching for the Na-O system was performed using Crystal Structure Analysis by Particle Swarm Optimization (CALYPSO) [35-37], an established method that has successfully predicted high-pressure structures in many systems [38-41]. The underlying structural relaxations and electronic structure calculations were performed using the Vienna ab initio Simulation Package (VASP) [42] with the Perdew-Burke-Ernzerhof generalized gradient approximation functional [43]. We used the projector augmented wave (PAW) [44] method to describe the valence electrons of the $\mathrm{Na}\left(2 s^{2} 2 p^{6} 3 s^{1}\right)$ and $\mathrm{O}$ $\left(2 s^{2} 2 p^{4}\right)$ atoms. We use a kinetic energy cutoff of $400 \mathrm{eV}$ and k-point sampling with $0.3 \AA^{-1}$ grid spacing. Each structure searching calculation generated 1200-1500 structures. After the structure searching, a kinetic energy cutoff of $1000 \mathrm{eV}$ and dense k-point sampling with grid spacing of $0.1 \AA^{-1}$ were used to ensure that enthalpy calculations were well converged to $\sim 1 \mathrm{meV}$ /atom. Phonon calculations with a supercell were performed using the PHONOPY code [45]. Electron localization functions (ELFs) were drawn using VESTA software [46], and Bader's quantum theory was adopted to calculate charge transfer [47].

\section{Results and Discussion}

\subsection{Stable $\mathrm{Na}-\mathrm{O}$ Compounds at High Pressure}

Our extensive searches for crystal structures of $\mathrm{Na}_{x} \mathrm{O}_{\mathrm{y}}(\mathrm{x}=1-4$ and $\mathrm{y}=1-5)$ considered pressures of 50,100,200, and $300 \mathrm{GPa}$ with simulation cells having up to four formula units (f.u.) for each fixed composition using CALYPSO methodology, which allows efficiently finding stable structures given only the chemical composition [35-37]. All the candidate structures were relaxed using the VASP code [42], and thermodynamic stabilities were 
systematically investigated by calculating the formation enthalpies relative to $\mathrm{Na}$ and $\mathrm{O}$ at the corresponding pressure. The enthalpy of formation per atom is calculated as follows:

$$
\Delta H=\left[H\left(\mathrm{Na}_{x} \mathrm{O}_{y}\right)-x H(\mathrm{Na})-y H(\mathrm{O})\right] /(x+y)
$$

Convex hull data at $0 \mathrm{~K}$ under different pressures (summarized in Figure 1a) show the stable compounds and phases as lying on the global stability line of the convex hull. The open symbols on the dotted lines represent unstable or metastable, and they decompose into other $\mathrm{Na}_{\mathrm{x}} \mathrm{O}_{\mathrm{y}}$ compounds or elemental solid $\mathrm{Na}$ and $\mathrm{O}$.
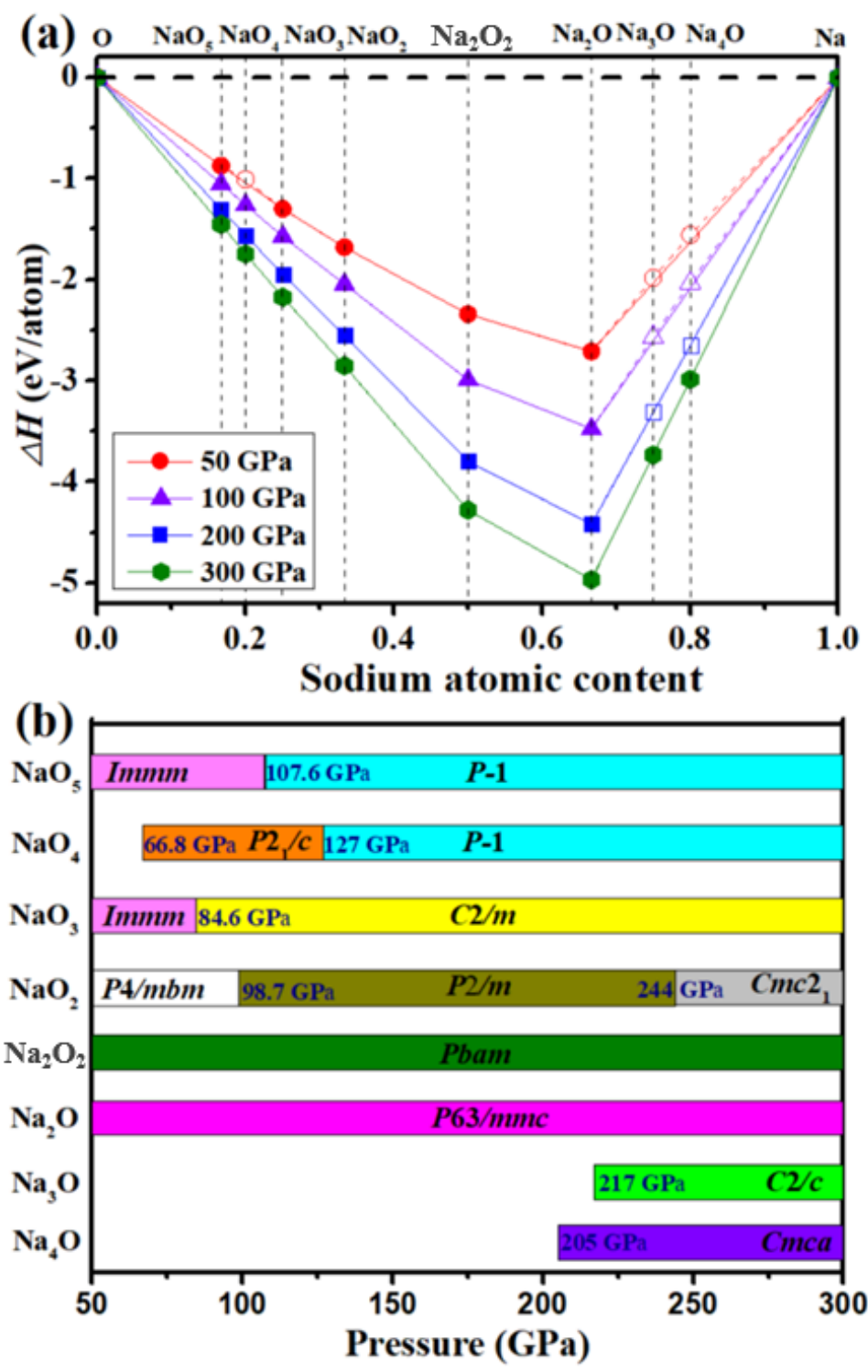

Figure 1. (a) Calculated formation enthalpy $(\Delta H)$ for each $\mathrm{Na}_{\mathrm{x}} \mathrm{O}_{\mathrm{y}}$ composition relative to $\mathrm{O}$ and $\mathrm{Na}$ at $0 \mathrm{~K}$. Solid symbols represent stable compounds, and open symbols represent metastable compounds. (b) Pressure range and structure of each stable compound. Na adopted the following structures: $\mathrm{Na}-$ bcc, $\mathrm{Na}-$ fcc, $\mathrm{Na}-\mathrm{cI} 16, \mathrm{Na}-\mathrm{oP} 8$, and $\mathrm{Na}-\mathrm{hP} 4[29,48-51]$, and $\mathrm{O}$ adopted $\zeta$ phases with $\mathrm{C} 2 / \mathrm{m}$ symmetry [52].

The calculated formation enthalpies of $\mathrm{Na}_{\mathrm{x}} \mathrm{O}_{\mathrm{y}}$ compounds in Figure 1a show that already known compounds of $\mathrm{Na}_{2} \mathrm{O}, \mathrm{Na}_{2} \mathrm{O}_{2}, \mathrm{NaO}_{2}$, and $\mathrm{NaO}_{3}$ lie on the convex hulls at the whole pressure range. $\mathrm{NaO}_{3}$ is known to possess an $\operatorname{Im} 2 m$ phase at ambient pressure [11]. Yang [5] reported $\mathrm{NaO}_{2}$ to have three stable high-pressure phases (Pnnm, 
Immm, and $P 4 / \mathrm{mbm}$ ) between 0 and $50 \mathrm{GPa}$. It has been reported that $\mathrm{Na}_{2} \mathrm{O}_{2}$ is stable in $A m m 2$ (distorted $P \overline{6}_{2} m$ ) and $P 2_{1} / c$ phases at low temperature [8]. However, the $P \overline{6}_{2} m$ and Pbam structures become the most stable at elevated temperature under pressures up to $300 \mathrm{GPa}$ [9]. $\mathrm{Na}_{2} \mathrm{O}$ undergoes phase transition from a cubic antifluorite $(F m \overline{3} m)$ structure to an orthorhombic anticotunnite structure (Pnma), and then to a Ni $2_{2}$ In-type $\left(\mathrm{PG}_{3} / \mathrm{mmc}\right)$ structure [10].

At elevated pressures, four new phases $\left(P 2 / m\right.$ and $\mathrm{Cmc}_{1} \mathrm{NaO}_{2}$, Immm and $\mathrm{C} 2 / \mathrm{m}$ $\mathrm{NaO}_{3}$ ) of the compounds with known stoichiometry were found. Moreover, new stoichiometries $\mathrm{NaO}_{5}, \mathrm{NaO}_{4}, \mathrm{Na}_{4} \mathrm{O}$, and $\mathrm{Na}_{3} \mathrm{O}$ became thermodynamically stable. An Immm phase of $\mathrm{NaO}_{5}$ stabilized at $50 \mathrm{GPa}$, and then transformed to a $P-1$ phase at $107.6 \mathrm{GPa}$. $\mathrm{NaO}_{4}$ stabilized in a $\mathrm{P}_{1} / \mathrm{c}$ phase above $66.8 \mathrm{GPa}$, and then transformed to a $P-1$ phase at $127 \mathrm{GPa} . \mathrm{Na}_{3} \mathrm{O}$ stabilized at $217 \mathrm{GPa}$ in a $\mathrm{C} / 2 c$ structure, and $\mathrm{Na}_{4} \mathrm{O}$ stabilized at $205 \mathrm{GPa}$ in a $\mathrm{Cmca}$ structure. To provide further information potentially useful for experimental synthesis, Figure $1 \mathrm{~b}$ shows calculated pressure-composition diagrams of the stable $\mathrm{Na}-$ O compounds. All of the predicted compounds were dynamically stable without any imaginary phonon modes in the whole Brillouin zone (Figure S1 in the Supplementary Materials). Table S1 gives detailed structural information, and auxiliary POSCAR files are added below Table S1 in the Supplementary Materials.

\subsection{O-Rich Compounds}

The O-rich compounds showed a remarkable feature of having all $\mathrm{O}$ atoms as quasimolecular $\mathrm{O}_{2}$ units. In addition to the previously proposed structures, new structures and stoichiometries were found, as discussed below in detail. To analyze these new structures, we calculated the $\mathrm{O}-\mathrm{O}$ bond lengths and Bader charges in established structures of $\mathrm{C} / 2 m \mathrm{O}_{2}$ [52], $\mathrm{Pbam} \mathrm{Na}_{2} \mathrm{O}_{2}$ [9], $P 4 / m b m \mathrm{NaO}_{2}$ [5], and $P 6_{3} / m m c \mathrm{Na}_{2} \mathrm{O}$ [10] at pressures of 50-300 GPa for comparison (Table S2).

For $\mathrm{NaO}_{2}$, in addition to three previously proposed structures (Pnnm, Immn, and $\mathrm{P}_{4} / \mathrm{mbm}$ ) [5], two new structures were found: $P 2 / m$ ( $2 \mathrm{f}$.u./cell) and $C m c 2_{1}$ ( $4 \mathrm{f}$.u./cell). The former contained one $\mathrm{Na}$ atom at the $2 \mathrm{~m}$ position and two inequivalent $\mathrm{O}$ atoms at $2 \mathrm{~m}$ sites. The O-O distances were 1.22 and $1.28 \AA$ at $200 \mathrm{GPa}$. Within this structure, each $\mathrm{Na}$ atom was coordinated with $10 \mathrm{O}$ atoms, forming pentagonal prisms (Figure 2a). The calculated Bader charges were -0.71 for O1-O1 and -0.94 for $\mathrm{O} 2-\mathrm{O} 2$ quasimolecular $\mathrm{O}_{2}$ units, indicating that the oxidation state of the two quasimolecular $\mathrm{O}_{2}$ units in $P 2 / m \mathrm{NaO}_{2}$ was -1 . These results confirm that this species can be viewed as a superoxide group $\mathrm{O}_{2}{ }^{-}$. $C m c 2_{1} \mathrm{NaO}_{2}$ stabilized above $244 \mathrm{GPa}$ and consisted of two inequivalent $\mathrm{Na}$ atoms at the $4 a$ position and four inequivalent $\mathrm{O}$ atoms at the $4 \mathrm{a}$ sites (Figure $2 \mathrm{~b}$ ). Within the $C m c 2_{1}$ structure, $\mathrm{Na} 1$ and $\mathrm{Na} 2$ atoms were coordinated with 10 and eight $\mathrm{O}$ atoms, respectively. The O1-O2 distance was $1.16 \AA$, and the calculated Bader charges of -0.25 at 300 GPa imply an intermediate bonding situation. The O3-O4 distance was $1.34 \AA$, and the calculated Bader charges were -1.39 at $300 \mathrm{GPa}$, comparable to the $1.37 \AA$ distance and -1.62 charge transfer in the peroxide $\left(\mathrm{O}_{2}{ }^{2-}\right)$ of $\mathrm{Na}_{2} \mathrm{O}_{2}$ at $300 \mathrm{GPa}$ (Table S2). These results confirm that the $\mathrm{O} 3-\mathrm{O} 4$ quasimolecular $\mathrm{O}_{2}$ units can be viewed as $\mathrm{O}_{2}{ }^{2-}$ units, which were first observed in superoxide. This indicates that the superoxide group is not maintained in $\mathrm{NaO}_{2}$ with increasing pressure.

An $\operatorname{Im} 2 m$ phase of $\mathrm{NaO}_{3}$ containing unusual ozone anions at ambient pressure was previously reported [11]. Our calculations found two new $\mathrm{NaO}_{3}$ phases (Immm (2 f.u./cell) and $\mathrm{C} 2 / \mathrm{m}$ ( 2 f.u./cell)) whose $\mathrm{O}$ atoms existed as quasimolecular $\mathrm{O}_{2}$ units rather than ozone anions. The Immm structure contained one $\mathrm{Na}$ atom at the 4e position and two inequivalent $\mathrm{O}$ atoms at the $8 \mathrm{~m}$ and $4 \mathrm{f}$ sites (Figure 2c). The $\mathrm{Na}$ was coordinated with 10 $\mathrm{O}$ atoms; $\mathrm{O} 1$ was coordinated with three $\mathrm{Na}$ atoms, whereas $\mathrm{O} 2$ was coordinated with two $\mathrm{Na}$ atoms and one $\mathrm{O} 2$ atom (Figure 2c). The $\mathrm{O} 2-\mathrm{O} 2$ bond length of $1.28 \AA$ is close to the distance within the superoxide group $\left(\mathrm{O}_{2}^{-}\right)$in $\mathrm{NaO}_{2}(1.31 \AA)$ at $50 \mathrm{GPa}$. The calculated Bader charge of the $\mathrm{O} 2-\mathrm{O} 2$ quasimolecular $\mathrm{O}_{2}$ units was -0.67 , comparable to that in $\mathrm{NaO}_{2}$ (-0.84; Table S2). These results confirm that $\mathrm{O} 2-\mathrm{O} 2$ quasimolecular $\mathrm{O}_{2}$ units can 
be viewed as $\mathrm{O}_{2}^{-}$units with a -1 formal oxidation state. The O1-O1 distance in Immm $\mathrm{NaO}_{3}$ was $1.24 \AA$ at $50 \mathrm{GPa}$, lying between that in neutral molecular oxygen $(1.20 \AA$ at $50 \mathrm{GPa})$ and the superoxide anion $\mathrm{O}_{2}{ }^{-}(1.31 \AA$ at $50 \mathrm{GPa})$. The calculated Bader charge of O1-O1 quasimolecular $\mathrm{O}_{2}$ units was -0.39 . The calculated Bader charge and O1-O1 distance suggest that the $\mathrm{O} 1-\mathrm{O} 1$ quasimolecular $\mathrm{O}_{2}$ units had an intermediate bonding situation. In the $\mathrm{C} 2 / \mathrm{m} \mathrm{NaO}_{3}$ structure, the $\mathrm{Na}$ atom was coordinated with nine $\mathrm{O}$ atoms, and the $\mathrm{O}-\mathrm{O}$ distances were 1.20 and $1.21 \AA$ at $300 \mathrm{GPa}$ (Figure 2d). The $\mathrm{O}-\mathrm{O}$ distance and Bader charges (Table S1) suggest these quasimolecular $\mathrm{O}_{2}$ units had an intermediate bonding situation that did not coincide with that of any known $\mathrm{O}_{2}$ functional group.

(a)

(c)
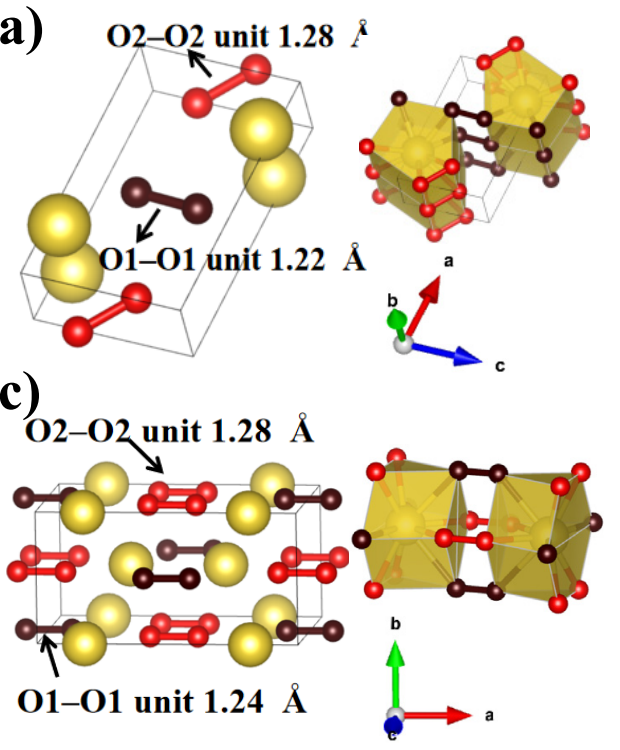

(e)

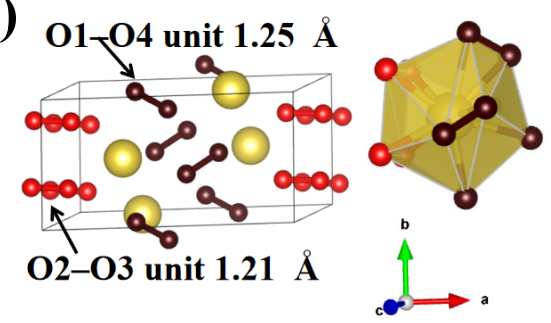

(g)
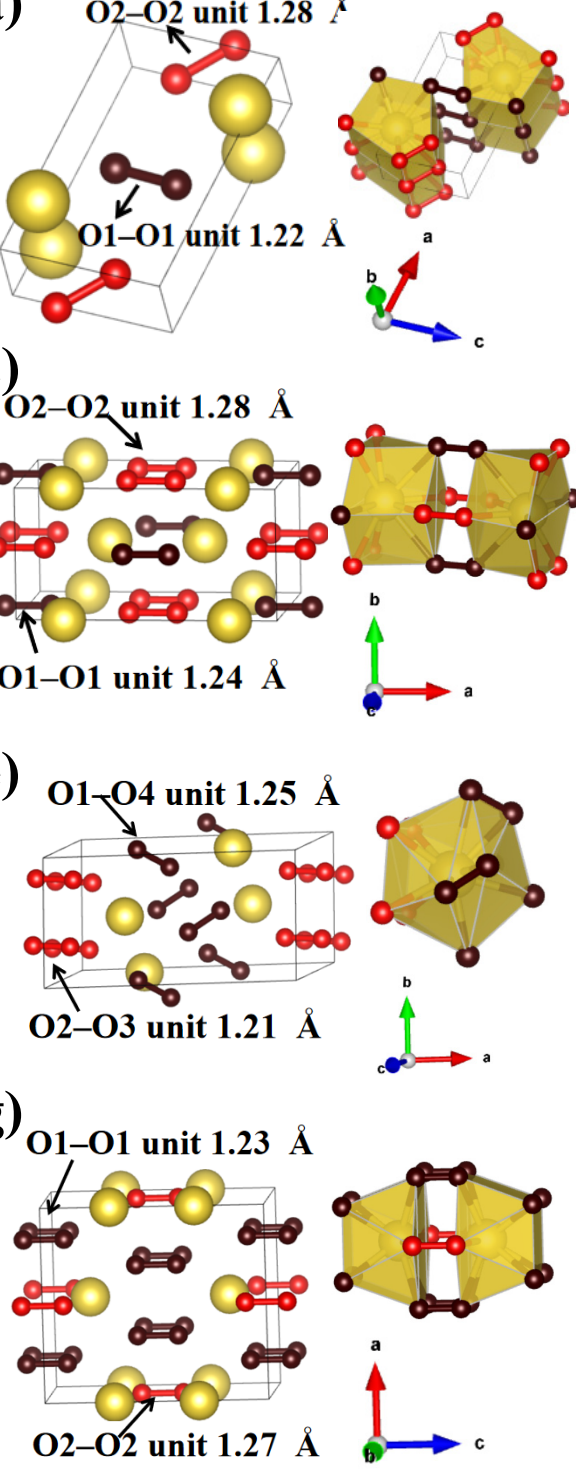

(b)

(d)
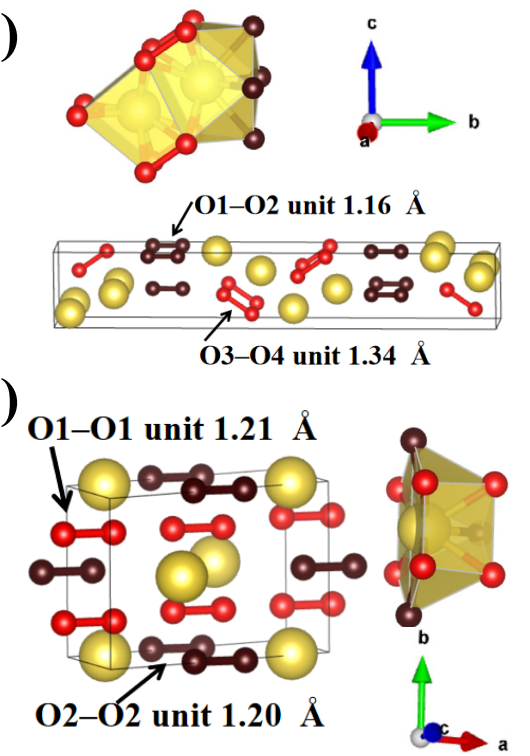

(f)

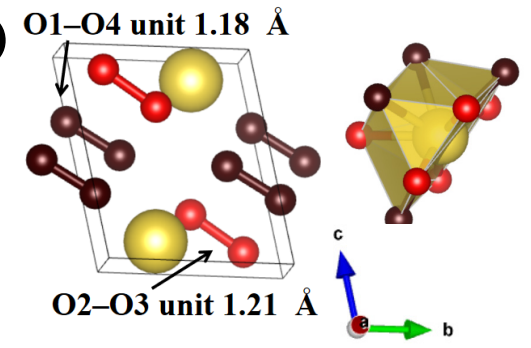

(h)

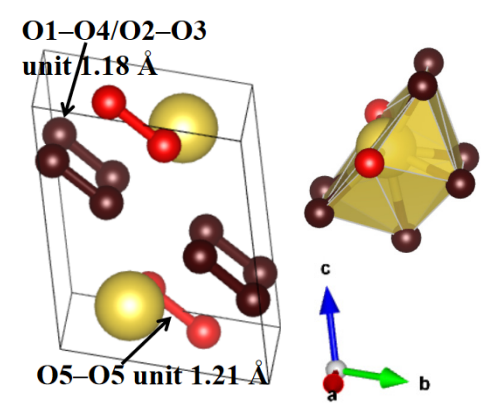

Figure 2. Crystal structures of the predicted O-rich Na-O compounds: (a) $P 2 / m \mathrm{NaO}_{2}$ at $200 \mathrm{GPa}$; (b) $C m c 2_{1} \mathrm{NaO}_{2}$ at $300 \mathrm{GPa}$; (c) Immm $\mathrm{NaO}_{3}$ at $50 \mathrm{GPa}$; (d) $C 2 / m \mathrm{NaO}_{3}$ at $300 \mathrm{GPa}$; (e) $P 2_{1} / \mathrm{c} \mathrm{NaO}_{4}$ at $120 \mathrm{GPa}$; (f) $P-1 \mathrm{NaO}_{4}$ at $300 \mathrm{GPa}$; (g) Immm NaO 5 at $50 \mathrm{GPa}$; (h) $P-1 \mathrm{NaO}_{5}$ at $300 \mathrm{GPa}$. Small spheres (dark and light red) represent $\mathrm{O}$ atoms; yellow spheres denote $\mathrm{Na}$ atoms.

$\mathrm{NaO}_{4}$ stabilized in a $P 2_{1} / c$ structure $(4 \mathrm{f} . \mathrm{u}$./cell) above $66.8 \mathrm{GPa}$. The structure had one $\mathrm{Na}$ atom at the $4 \mathrm{e}$ position and four inequivalent $\mathrm{O}$ atoms at the $4 \mathrm{e}$ sites. The $\mathrm{O}-\mathrm{O}$ distances were $1.21 \AA$ and $1.25 \AA$ at $120 \mathrm{GPa}$. Each Na was surrounded by $11 \mathrm{O}$ atoms, forming an irregular polyhedron (Figure 2e). At $127 \mathrm{GPa}$, the $P 2_{1} / c$ structure transitioned 
to $P-1 \mathrm{NaO}_{4}$ (2 f.u./cell) with $\mathrm{O}-\mathrm{O}$ distances of 1.18 and $1.21 \AA$ at $300 \mathrm{GPa}$ (Figure 2f). The $\mathrm{O}-\mathrm{O}$ distances and Bader charges (Table S1) indicate that all quasimolecular $\mathrm{O}_{2}$ units in $P 2_{1} / \mathrm{c}$ and $P-1 \mathrm{NaO}_{4}$ phases had an intermediate bonding situation that did not coincide with that shown by any known $\mathrm{O}_{2}$ functional group. Previous studies of lithium oxides at high pressure $[53,54]$ reported $\mathrm{LiO}_{4}$ phases with space groups of Ibam or $I 4 / \mathrm{mcm}$ at $50 \mathrm{GPa}$. The more accurate calculation used here for the $\mathrm{Na}-\mathrm{O}$ system found the $P 2_{1} / c$ structure to be energetically favorable at $50 \mathrm{GPa}$.

Our calculations for $\mathrm{NaO}_{5}$, the most O-rich $\mathrm{Na}-\mathrm{O}$ composition, found two crystal structures with $I m m m$ ( 2 f.u./cell) and P-1 (2 f.u./cell) symmetries. The Immm contained one $\mathrm{Na}$ atom at the $4 \mathrm{i}$ position and two inequivalent $\mathrm{O}$ atoms at the $16 \mathrm{o}$ and $4 \mathrm{j}$ sites (Figure $2 \mathrm{~g}$ ). The $\mathrm{Na}$ atom was coordinated with $10 \mathrm{O}$ atoms, and each $\mathrm{O}$ atom was coordinated with two $\mathrm{Na}$ atoms and one $\mathrm{O}$ atom. The $\mathrm{O}-\mathrm{O}$ distances (1.23 and $1.27 \AA$ at $50 \mathrm{GPa})$ were intermediate between those in neutral molecular oxygen (1.20 $\AA$ at $50 \mathrm{GPa})$ and in the superoxide anion $\mathrm{O}_{2}{ }^{-}(1.31 \AA$ at $50 \mathrm{GPa})$. Compressing Immm $\mathrm{NaO}_{5}$ transformed it into $P-1 \mathrm{NaO}_{5}$ at $107.6 \mathrm{GPa}$. This structure had each $\mathrm{Na}$ atom coordinated with nine $\mathrm{O}$ atoms (Figure 2i). The $\mathrm{O}-\mathrm{O}$ bond lengths (1.18 and $1.21 \AA$ ) were much shorter than those in the Immm structure. The calculated Bader charges and $\mathrm{O}-\mathrm{O}$ distances indicate that $\mathrm{NaO}_{5}$ and $\mathrm{NaO}_{4}$ showed similar results, implying an intermediate bonding situation of all the oxygen pairs, which did not coincide with that shown by any known $\mathrm{O}_{2}$ functional group. Enhancing the $\mathrm{O}$ content in transition metal oxides can generally obtain $\mathrm{O}_{2}{ }^{2-}$ or $\mathrm{O}^{2-}$ groups [55-57], whereas the high-oxygen-content $\mathrm{Na}-\mathrm{O}$ compounds of the present study did not give these groups.

To understand the electronic structures of O-rich compounds, we calculated the projected density of states (PDOS). All the O-rich compounds shared similar features. Thus, we present the PDOS of the lower-pressure structures for each compound in Figure 3 as representatives and provide the PDOS of higher-pressure structures in Figure S2 in the Supplementary Materials. As can be seen form Figure 3, the $\mathrm{O} 2 p$ states dominated the valance bands, while the contribution of $\mathrm{Na}$ to the valance states was negligible since electrons were transferred from $\mathrm{Na}$ to $\mathrm{O}$. However, there were insufficient $\mathrm{Na}$ atoms to donate their electrons to fully occupy the $\mathrm{O} 2 p$ states. All these O-rich compounds were electron-deficient, and the partially occupied $\mathrm{O} 2 p$ electronic bands led to metallicity. All the metallic O-rich compounds were nonmagnetic, similar to $\mathrm{YO}_{3}$ [55], $\mathrm{LiO}_{2}$ [54], and $\mathrm{NaO}_{2}$ [5]. This can be attributed to pressure-induced magnetic collapse [58].

\subsection{Na-Rich Compounds}

Compression stabilized $\mathrm{Na}_{3} \mathrm{O}$ at $217 \mathrm{GPa}$ with a $\mathrm{C} 2 / \mathrm{c}$ structure and $\mathrm{Na}_{4} \mathrm{O}$ at $205 \mathrm{GPa}$ with a $\mathrm{Cmca}$ structure. In the $\mathrm{C} / \mathrm{c} \mathrm{Na}_{3} \mathrm{O}$ structure, the $\mathrm{O}$ atom was surrounded by $11 \mathrm{Na}$ atoms, forming a 17-faced polyhedron. The distance between neighboring oxygen atoms was $2.65 \AA$ at $300 \mathrm{GPa}$ (Figure 4a). In $\mathrm{Cmca} \mathrm{Na} \mathrm{Na}_{4} \mathrm{O}$, the coordination number of $\mathrm{O}$ increased to 12 , and neighboring oxygen atoms were $2.73 \AA$ apart at $300 \mathrm{GPa}$ (Figure $4 \mathrm{~d}$ ). Both phases had all $\mathrm{O}$ atoms as oxide ions rather than quasimolecular $\mathrm{O}_{2}$ units. The Na-rich $\mathrm{Na}-\mathrm{O}$ materials are naturally electron-rich systems, making them potential candidate electride materials. Electrides have some electrons localized at interstitial regions, rather than being attached to atoms, and these electrons behave as anions [59]. According to the dimensionality of the anionic electrons and corresponding interstitial spaces where the electrons are trapped, electrides can be classified into zero-dimensional (0D), onedimensional (1D), two-dimensional (2D), and three-dimensional (3D) electrides [60]. Miao and Hoffmann attributed the formation of high-pressure electrides to external pressure inducing changes in energy between the interstitial space and the valence orbitals of atoms $[15,61]$. 

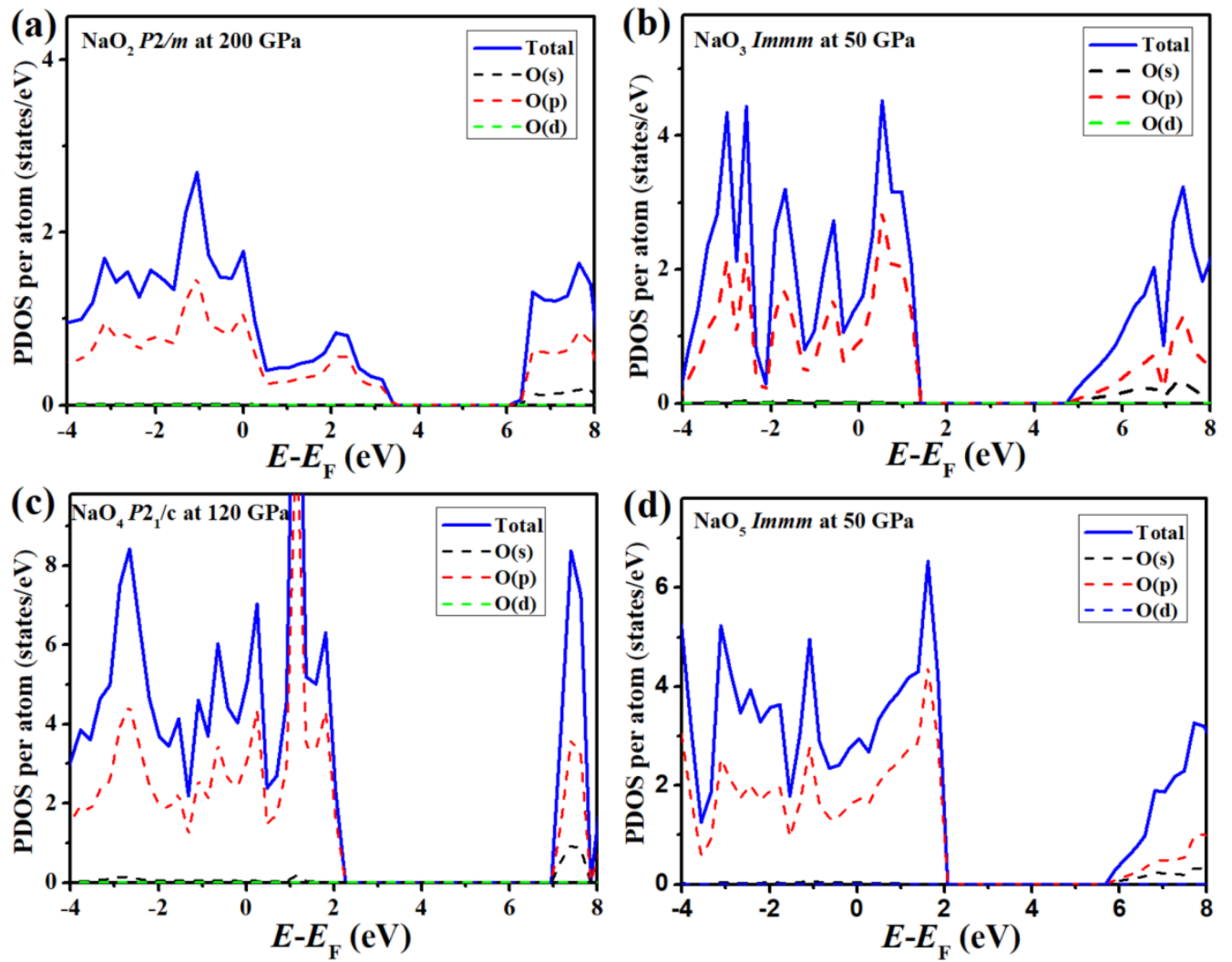

Figure 3. PDOS of the predicted $\mathrm{O}-$ rich $\mathrm{Na}-\mathrm{O}$ compounds: (a) $P 2 / m \mathrm{NaO}_{2}$ at $200 \mathrm{GPa}$; (b) Immm $\mathrm{NaO}_{3}$ at $50 \mathrm{GPa}$; (c) $P 2_{1} / c \mathrm{NaO}_{4}$ at $120 \mathrm{GPa}$; (d) Immm $\mathrm{NaO}_{5}$ at $50 \mathrm{GPa}$. The PDOS of $\mathrm{Na}$ is not shown, as it had negligible contributions near the Fermi energy. The Fermi energy $\left(\mathrm{E}_{\mathrm{F}}\right)$ was set to zero.

(a)

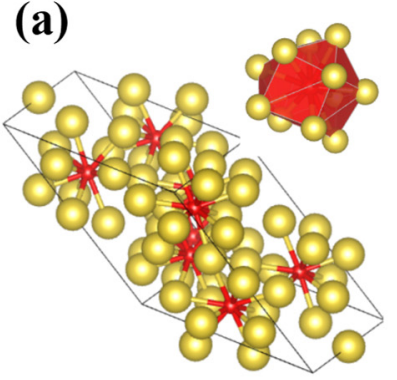

(d)
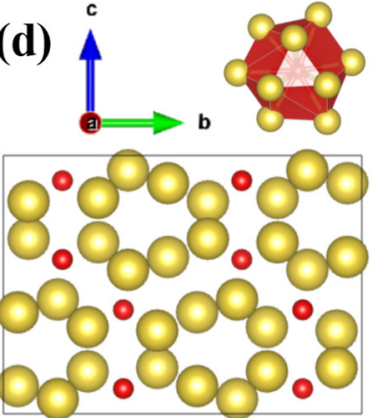

(b)

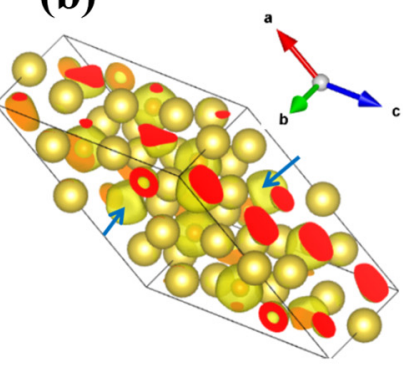

(e)

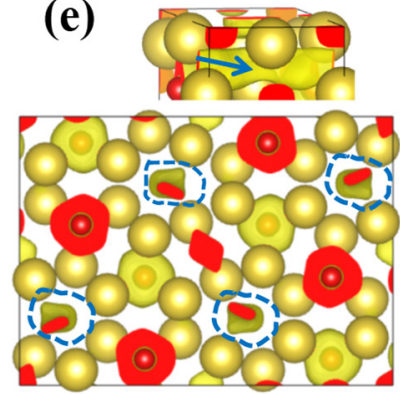

(c)

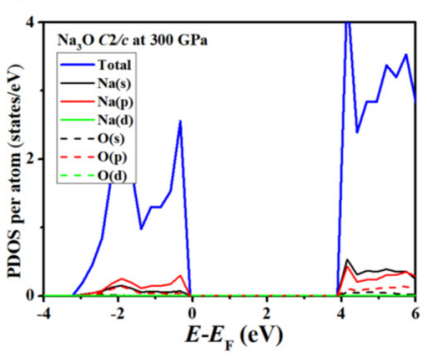

(f)

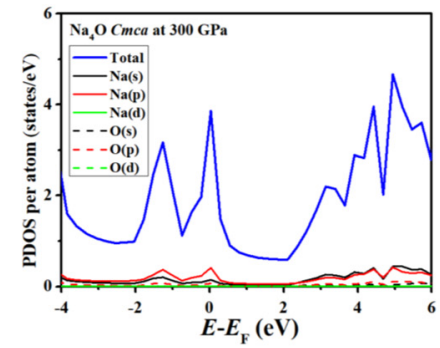

Figure 4. (a,d) Crystal structures, (b,e) ELF, and (c,f) PDOS of predicted Na-rich Na-O compounds at 300 GPa: (a-c) $C 2 / c \mathrm{Na}_{3} \mathrm{O}$ and $(\mathbf{d}-\mathbf{f}) \mathrm{Cmca} \mathrm{Na}_{4} \mathrm{O}$. O atoms are represented by bright red spheres; yellow spheres denote $\mathrm{Na}$ atoms. The interstitial electron regions are marked with blue arrows and dashed lines. 
The calculated Bader charges for the $\mathrm{C} 2 / \mathrm{c} \mathrm{Na} \mathrm{Na}_{3} \mathrm{O}$ and $\mathrm{Cmca} \mathrm{NaO}_{4}$ phases show that charge was transferred from $\mathrm{Na}$ to both $\mathrm{O}$ and interstitial spaces (Table S1). The electrons provided by $\mathrm{Na}$ atoms were first captured by $\mathrm{O}$ atoms to reach a stable eight-electron closedshell configuration. Further electrons from the Na were then trapped in the interstitial spaces, favoring electride formation. Subsequent ELF analysis characterized the localization of the excess electrons. The ELF maps for $\mathrm{C} 2 / \mathrm{c} \mathrm{Na} \mathrm{Na}_{3} \mathrm{O}$ and $\mathrm{Cmca} \mathrm{Na}_{4} \mathrm{O}$ with an isosurface value of 0.7 at $300 \mathrm{GPa}$ (Figure $4 \mathrm{~b}, \mathrm{e}$ ) clearly show electrons localized in the interstices of the crystal, suggesting electride formation. Anionic electrons in the $\mathrm{C} 2 / \mathrm{c} \mathrm{Na} 3 \mathrm{O}$ electride were limited to 0D (Figure $4 \mathrm{~b}$ ). The anionic electrons in 0D electrides are completely localized in the void of the crystal and do not contribute to the conductivity of the system. Thus, $0 \mathrm{D}$ electrides tend to form semiconductors or insulators, such as the insulating phase of Na-hP4 [29] at 320 GPa and semiconductor phase of Li-aba2-40 [39] at 70 GP. The other structure, $\mathrm{Cmca} \mathrm{Na}_{4} \mathrm{O}$, was a 1D electride in which anionic electrons were delocalized in a channel, in which the electrons could move along the channel, leading to a metallic nature. The electronic properties of both structures were explored through PDOS calculations (Figure $4 \mathrm{c}, \mathrm{f}) . \mathrm{C} 2 / \mathrm{c} \mathrm{Na}_{3} \mathrm{O}$ was clearly insulating due to $\mathrm{Na}-\mathrm{O}$ ionic bonding and the localized $0 D$ interstitial electrons. However, $\mathrm{Cmca} \mathrm{Na} \mathrm{Na}_{4} \mathrm{O}$ was metallic; the states around the Fermi level were all mainly contributed by the $\mathrm{Na} 3 p$ and $3 s$ orbitals and $\mathrm{O} 2 p$ orbitals (Figure $4 \mathrm{f}$ ). Similar electride suboxides, $\mathrm{Li}_{6} \mathrm{O}$ [54] and $\mathrm{Mg}_{3} \mathrm{O}_{2}$ [62], have also been reported at high pressure. $\mathrm{Na}_{4} \mathrm{O}$ is a non-superconducting metal electride.

To show the general trend of electronic properties of the Na-O compounds, we summarize the DOSs at the Fermi level for various Na-O compounds at $300 \mathrm{GPa}$ as a function of Na content in Figure S3 in the Supplementary Materials. It can be seen that all the O-rich compounds were metallic due to their electron-deficient character as aforementioned. For the $\mathrm{Na}_{2} \mathrm{O}_{2}$ and $\mathrm{Na}_{2} \mathrm{O}$ compounds, the octet rule was achieved as the peroxide $\mathrm{O}_{2}{ }^{2-}$ group or $\mathrm{O}^{2-}$ anions acquired exactly two electrons from the two Na atoms, leading to an insulating character. The Na-rich compounds, $\mathrm{Na}_{3} \mathrm{O}$ and $\mathrm{Na}_{4} \mathrm{O}$, should be metallic due to the existence of excess electrons. However, the formation of the $0 \mathrm{D}$ electride made $\mathrm{Na}_{3} \mathrm{O}$ an insulator.

\section{Conclusions}

In summary, we used systematic structure exploration and first-principles calculations to construct a high-pressure stability field and convex hull diagram of the $\mathrm{Na}-\mathrm{O}$ system with different stoichiometries at pressures of 50-300 GPa. Four previously unknown stoichiometries $\left(\mathrm{NaO}_{5}, \mathrm{NaO}_{4}, \mathrm{Na}_{4} \mathrm{O}\right.$, and $\left.\mathrm{Na}_{3} \mathrm{O}\right)$ and four new phases of known stoichiometries $\left(P 2 / m\right.$ and $C m c 2_{1} \mathrm{NaO}_{2}$ and $I m m m$ and $\left.C 2 / m \mathrm{NaO}_{3}\right)$ were predicted to be thermodynamically stable. Remarkably, the O-rich stoichiometries showed all $\mathrm{O}$ atoms to exist in quasimolecular $\mathrm{O}_{2}$ units in a metallic state. Calculated $\mathrm{O}-\mathrm{O}$ bond lengths and Bader charges were used to explore the electronic properties and chemical bonding of the O-rich compounds. The Na-rich compounds stabilized at extreme pressures $(\mathrm{P}>200 \mathrm{GPa})$ as electrides with strong interstitial electron localization. Electrons in $\mathrm{C} 2 / \mathrm{c} \mathrm{Na} \mathrm{Na}_{3} \mathrm{O}$ localized to $0 \mathrm{D}$, making the compound an insulator. In contrast, $\mathrm{Cmca} \mathrm{Na}_{4} \mathrm{O}$ was revealed as a $1 \mathrm{D}$ electride with metallic features. This work provides guidance for further experimental studies of the properties of the $\mathrm{Na}-\mathrm{O}$ system.

Supplementary Materials: The following are available online at https://www.mdpi.com/article/ 10.3390/ma14247650/s1: Figure S1. Phonon dispersion curves of the predicted Na-O compounds at the respective stable pressures; Figure S2. The PDOS of the predicted O-rich Na-O compounds; Figure S3. The DOS at the Fermi level versus sodium content of $\mathrm{Na}-\mathrm{O}$ compounds at $300 \mathrm{GPa}$; Table S1. Structure details of the conventional unit cell of $\mathrm{Na}_{x} \mathrm{O}_{\mathrm{y}}$ from the CALYPSO structure searches at different pressures and auxiliary POSCAR files; Table S2. Calculated O-O bond lengths and Bader charges. 
Author Contributions: Conceptualization, X.Q. and J.Y.; supervision, J.L., X.Z. and J.Y.; resources, L.Y. and J.L.; writing—original draft preparation, L.Y. and Y.Z.; writing-review and editing, Y.C., D.W., and J.L. All authors read and agreed to the published version of the manuscript.

Funding: This research was funded by the National Natural Science Foundation of China, grant numbers 11904129 and 22078124, the Program for the Development of Science and Technology of Jilin Province, grant numbers 20190103040JH, 20190103039JH, YDZJ202101ZYTS065, 20190103043JH, and 20190103100JH, the Central Government Guided Local Science and Technology Development Fund for Basic Research of Jilin Province, grant number 202002015JC, the Scientific and Technological Research Project of the "13th Five-Year Plan" of Jilin Provincial Education Department, grant numbers JJKH20200408KJ and JJKH20200406KJ, and the Open Project of State Key Laboratory of Superhard Materials, Jilin University, grant numbers 201911 and 201908.

Institutional Review Board Statement: Not applicable.

Informed Consent Statement: Not applicable.

Data Availability Statement: The data presented in this study are available on request from the corresponding authors.

Conflicts of Interest: The authors declare no conflict of interest.

\section{References}

1. Hubbard, W.B. Planetary Interiors; Van Nostrand Reinhold: New York, NY, USA, 1984.

2. Vol'nov, I.I. Peroxides, Superoxides, and Ozonides of Alkali and Alkaline Earth Metals; Springer: Boston, MA, USA, 1966.

3. Song, K.; Agyeman, D.A.; Park, M.; Yang, J.; Kang, Y.M. High-Energy-Density Metal-Oxygen Batteries: Lithium-Oxygen Batteries vs Sodium-Oxygen Batteries. Adv. Mater. 2017, 29, 1606572. [CrossRef] [PubMed]

4. Hartmann, P.; Grübl, D.; Sommer, H.; Janek, J.; Bessler, W.G.; Adelhelm, P. Pressure Dynamics in Metal-Oxygen (Metal-Air) Batteries: A Case Study on Sodium Superoxide Cells. J. Phys. Chem. C 2014, 118, 1461-1471. [CrossRef]

5. Deng, N.; Yang, G.; Wang, W.; Qiu, Y. Structural transitions and electronic properties of sodium superoxide at high pressures. RSC Adv. 2016, 6, 67910. [CrossRef]

6. Yang, S.; Siegel, D.J. Intrinsic Conductivity in Sodium-Air Battery Discharge Phases: Sodium Superoxide vs Sodium Peroxide. Chem. Mater. 2015, 27, 3852-3860. [CrossRef]

7. Zhang, W.; Zhao, C.; Wu, X. Research Progresses on Interfaces in Solid-State Sodium Batteries: A Topic Review. Adv. Mater. Interfaces 2020, 7, 2001444. [CrossRef]

8. Jimlim, P.; Tsuppayakorn-aek, P. Theoretical predictions for low-temperature phases, softening of phonons and elastic stiffnesses, and electronic properties of sodium peroxide under high pressure. RSC Adv. 2019, 9, 30964-30975. [CrossRef]

9. Deng, N.; Wang, W.; Yang, G.; Qiu, Y. Structural and electronic properties of alkali metal peroxides at high pressures. RSC Adv. 2015, 5, 104337-104342. [CrossRef]

10. Čančarević, Ž.; Schön, J.C.; Jansen, M. Stability of alkali-metal oxides as a function of pressure: Theoretical calculations. Phys. Rev. B. 2006, 73, 224114. [CrossRef]

11. Lein, W.K.; Armbruster, K.; Jansen, M. Synthesis and crystal structure determination of sodium ozonide. Chem. Commun. 1998, 6, 707-708.

12. Carter, G.F.; Templeton, D.H. Polymorphism of Sodium Superoxide. J. Am. Chem. Soc. 1953, 75, 5247-5249. [CrossRef]

13. Zhang, L.; Wang, Y.; Lv, J.; Ma, Y. Materials discovery at high pressures. Nat. Rev. Mater. 2017, 2, 17005. [CrossRef]

14. Li, Y.; Hao, J.; Liu, H.; Li, Y.; Ma, Y. The metallization and superconductivity of dense hydrogen sulfifide. J. Chem. Phys. 2014, 140, 174712. [CrossRef]

15. Miao, M.-S.; Hoffmann, R. High-pressure electrides: The chemical nature of interstitial quasiatoms. J. Am. Chem. Soc. 2015, 137, 3631-3637. [CrossRef] [PubMed]

16. Pepin, C.M.; Geneste, G.; Dewaele, A.; Mezouar, M.; Loubeyre, P. Synthesis of $\mathrm{FeH}_{5}$ : A layered structure with atomic hydrogen slabs. Science 2017, 357, 382. [CrossRef]

17. Yang, G.; Wang, Y.; Peng, F.; Bergara, A.; Ma, Y. Gold as a 6p-element in dense lithium aurides. J. Am. Chem. Soc. 2016, 138, 4046-4052. [CrossRef]

18. Zhao, Z.; Zhang, S.; Yu, T.; Xu, H.; Bergara, A.; Yang, G. Predicted pressure-induced superconducting transition in electride Li 6 P. Phys. Rev. Lett. 2019, 122, 097002. [CrossRef] [PubMed]

19. Duan, D.; Liu, Y.; Tian, F.; Li, D.; Huang, X.; Zhao, Z.; Yu, H.; Liu, B.; Tian, W.; Cui, T. Pressure-induced metallization of dense $\left(\mathrm{H}_{2} \mathrm{~S}\right)_{2} \mathrm{H}_{2}$ with high-Tc superconductivity. Sci. Rep. 2014, 4, 6968. [CrossRef]

20. Gao, G.; Wang, L.; Li, M.; Zhang, J.; Howie, R.T.; Gregoryanz, E.; Struzhkin, V.V.; Wang, L.; Tse, J.S. Superconducting binary hydrides: Theoretical predictions and experimental progresses. Mater. Today Phys. 2021, 21, 100546. [CrossRef]

21. Einaga, M.; Sakata, M.; Ishikawa, T.; Shimizu, K.; Eremets, M.I.; Drozdov, A.P.; Troyan, I.A.; Hirao, N.; Ohishi, Y. Crystal structure of the superconducting phase of sulfur hydride. Nat. Phys. 2016, 12, 835-838. [CrossRef] [PubMed] 
22. Zhang, W.; Oganov, A.R.; Goncharov, A.F.; Zhu, Q.; Boulfelfel, S.E.; Lyakhov, A.O.; Stavrou, E.; Somayazulu, M.; Prakapenka, V.B.; Konôpková, Z. Unexpected stable stoichiometries of sodium chlorides. Science 2013, 342, 1502. [CrossRef]

23. Zhu, L.; Liu, H.; Pickard, C.J.; Zou, G.; Ma, Y. Reactions of xenon with iron and nickel are predicted in the Earth's inner core. Nat. Chem. 2014, 6, 644. [CrossRef] [PubMed]

24. Dewaele, A.; Worth, N.; Pickard, C.J.; Needs, N.W.R.J.; Pascarelli, S.; Mathon, O.; Mezouar, S.P.O.M.M.; Irifune, T. Synthesis and stability of xenon oxides $\mathrm{Xe}_{2} \mathrm{O}_{5}$ and $\mathrm{Xe}_{3} \mathrm{O}_{2}$ under pressure. Nat. Chem. 2016, 8, 784. [CrossRef]

25. Peng, F.; Sun, Y.; Pickard, C.J.; Needs, R.J.; Wu, Q.; Ma, Y. Hydrogen clathrate structures in rare earth hydrides at high pressures: Possible route to room-temperature superconductivity. Phys. Rev. Lett. 2017, 119, 1. [CrossRef]

26. Liu, H.; Naumov, I.I.; Hoffmann, R.; Ashcroft, N.W.; Hemley, R.J. Potential high-Tc superconducting lanthanum and yttrium hydrides at high pressures. Proc. Natl. Acad. Sci. USA 2017, 114, 6990. [CrossRef]

27. Somayazulu, M.; Ahart, M.; Mishra, A.K.; Geballe, Z.M.; Baldini, M.; Meng, Y.; Struzhkin, V.V.; Hemley, R.J. Evidence for superconductivity above $260 \mathrm{~K}$ in Lanthanum superhydride at megabar pressures. Phys. Rev. Lett. 2019, 122, 27001. [CrossRef] [PubMed]

28. Drozdov, A.P.; Eremets, M.I.; Troyan, I.A.; Ksenofontov, V.; Shylin, S.I. Conventional superconductivity at 203 kelvin at high pressures in the sulfur hydride system. Nature 2015, 525, 73-76. [CrossRef]

29. Ma, Y.; Eremets, M.; Oganov, A.R.; Xie, Y.; Trojan, I.; Medvedev, S.; Lyakhov, A.O.; Valle, M.; Prakapenka, V. Transparent dense sodium. Nature 2009, 458, 182-185. [CrossRef]

30. Dong, X.; Oganov, A.R.; Goncharov, A.F.; Stavrou, E.; Lobanov, S.; Saleh, G.; Qian, G.-R.; Zhu, Q.; Gatti, C.; Deringer, V.L.; et al. A stable compound of helium and sodium at high pressure. Nat. Chem. 2017, 9, 440-445. [CrossRef] [PubMed]

31. Wang, Y.; Xu, M.; Yang, L.; Yan, B.; Qin, Q.; Shao, X.; Zhang, Y.; Huang, D.; Lin, X.; Lv, J.; et al. Pressure-stabilized divalent ozonide $\mathrm{CaO}_{3}$ and its impact on Earth's oxygen cycles. Nat. Commun. 2020, 11, 4702. [CrossRef] [PubMed]

32. Hu, Q.; Kim, D.Y.; Yang, W.; Yang, L.; Meng, Y.; Zhang, L.; Mao, H. $\mathrm{FeO}_{2}$ and FeOOH under deep lower-mantle conditions and Earth's oxygen-hydrogen cycles. Nature 2016, 534, 241. [CrossRef]

33. Bykova, E.; Dubrovinsky, L.; Dubrovinskaia, N.; Bykov, E.B.N.D.M.; McCammon, C.; Ovsyannikov, S.V.; Liermann, H.-P.; Kupenko, I.; Chumakov, A.I.; Rüffer, R.; et al. Structural complexity of simple $\mathrm{Fe}_{2} \mathrm{O}_{3}$ at high pressures and temperatures. Nat. Commun. 2016, 7, 10661. [CrossRef] [PubMed]

34. Lavina, B.; Meng, Y. Unraveling the complexity of iron oxides at high pressure and temperature: Synthesis of $\mathrm{Fe}_{5} \mathrm{O}_{6}$. Sci. Adv. 2015, 1, e1400260. [CrossRef] [PubMed]

35. Wang, Y.; Lv, J.; Ma, Y.; Cui, T.; Zou, G. Superconductivity of $\mathrm{MgB}_{2}$ under Ultra high Pressure: A First-Principles Study. Phys. Rev. $B$ 2009, 80, 092505. [CrossRef]

36. Wang, Y.; Lv, J.; Zhu, L.; Ma, Y. CALYPSO: A Method for Crystal Structure Prediction. Comput. Phys. Commun. 2012, 183, 2063-2070. [CrossRef]

37. Lv, J.; Wang, Y.; Zhu, L.; Ma, Y. Particle-swarm structure prediction on clusters. J. Chem. Phys. 2012, 137, 084104. [CrossRef]

38. Zhu, L.; Wang, H.; Wang, Y.; Lv, J.; Ma, Y.; Cui, Q.; Ma, Y.; Zou, G. Substitutional Alloy of Bi and Te at High Pressure. Phys. Rev. Lett. 2011, 106, 18-21. [CrossRef]

39. Lv, J.; Wang, Y.; Zhu, L.; Ma, Y. Predicted Novel High-Pressure Phases of Lithium. Phys. Rev. Lett. 2011, 106, 015503. [CrossRef]

40. Li, Y.; Wang, L.; Liu, H.; Zhang, Y.; Hao, J.; Pickard, C.J.; Nelson, J.R.; Needs, R.J.; Li, W.; Huang, Y.; et al. Dissociation Products and Structures of Solid $\mathrm{H}_{2} \mathrm{~S}$ at Strong Compression. Phys. Rev. B 2016, 93, 020103. [CrossRef]

41. Zhang, J.; Lv, J.; Li, H.; Feng, X.; Lu, C.; Redfern, S.A.T.; Liu, H.; Chen, C.; Ma, Y. Rare Helium-Bearing Compound FeO ${ }_{2} \mathrm{He}$ Stabilized at Deep-Earth Conditions. Phys. Rev. Lett. 2018, 121, 255703. [CrossRef]

42. Kresse, G.; Furthmuller, J. Efficient Iterative Schemes for Ab Initio Total-Energy Calculations Using a Plane-Wave Basis Set. Phys. Rev. B 1996, 54, 11169-11186. [CrossRef]

43. Perdew, J.P.; Burke, K.; Ernzerhof, M. Generalized Gradient Approximation Made Simple. Phys. Rev. Lett. 1996, 77, 3865-3868. [CrossRef]

44. Blochl, P.E. Projector Augmented-Wave Method. Phys. Rev. B 1994, 50, 17953-17979. [CrossRef]

45. Togo, A.; Oba, F.; Tanaka, I. First-Principles Calculations of the Ferroelastic Transition between Rutile-Type and $\mathrm{CaCl}_{2}-\mathrm{Type} \mathrm{SiO}_{2}$. Phys. Rev. B 2008, 78, 134106. [CrossRef]

46. Momma, K.; Izumi, F. VESTA 3 for Three-Dimensional Visualization of Crystal. Volumetric and Morphology Data. J. Appl. Crystallogr. 2011, 44, 1272-1276. [CrossRef]

47. Bader, R.F.W. Atoms in Molecules. Acc. Chem. Res. 1985, 18, 9-15. [CrossRef]

48. Ma, Y.; Oganov, A.R.; Xie, Y. High-Pressure Structures of Lithium, Potassium, Rubidium Predicted by an Ab Initio Evolutionary Algorithm. Phys. Rev. B 2008, 78, 014102. [CrossRef]

49. Gregoryanz, E.; Lundegaard, L.F.; McMahon, M.I.; Guillaume, C.; Nelmes, R.J.; Mezouar, M. Structural Diversity of Sodium. Science 2008, 320, 1054-1057. [CrossRef]

50. Hanfland, M.; Loa, I.; Syassen, K. Sodium under Pressure: Bcc to Fcc Structural Transition and Pressure-Volume Relation to 100 GPa. Phys. Rev. B 2002, 65, 184109. [CrossRef]

51. Ackland, G.J.; Macleod, I.R. Origin of the Complex Crystal Structures of Elements at Intermediate Pressure. New J. Phys. 2004, 6, 138. [CrossRef] 
52. Ma, Y.; Oganov, A.R.; Glass, C.W. Structure of the metallic $\zeta$-phase of oxygen and isosymmetric nature of the $\varepsilon-\zeta$ phase transition: Ab initio simulation. Phys. Rev. B 2007, 76, 64101. [CrossRef]

53. Yang, W.; Kim, D.Y.; Yang, L.; Li, N.; Tang, L.; Amine, K.; Mao, H. Oxygen-Rich Lithium Oxide Phases Formed at High Pressure for Potential Lithium-Air Battery Electrode. Adv. Sci. 2017, 4, 1600453. [CrossRef]

54. Dong, X.; Hou, J.; Kong, J.; Cui, H.; Li, Y.; Oganov, A.R.; Li, K.; Zheng, H.; Zhou, X.; Wang, H.-T. Predicted lithium oxide compounds and superconducting low-pressure $\mathrm{LiO}_{4}$. Phys. Rev. B 2019, 100, 144104. [CrossRef]

55. Yang, Q.; Lin, J.; Li, F.; Zhang, J.; Zurek, E.; Yang, G. Pressure-induced yttrium oxides with unconventional stoichiometries and novel properties. Phys. Rev. Mater. 2021, 5, 044802. [CrossRef]

56. Zhang, J.; Oganov, A.R.; Li, X.; Esfahani, M.M.D.; Dong, H. First-principles investigation of Zr-O compounds, their crystal structures, and mechanical properties. J. Appl. Phys. 2017, 121, 155104. [CrossRef]

57. Bouibes, A.; Zaoui, A. Investigating new polyphorms of $\mathrm{Zn}-\mathrm{O}$ from variable composition. Solid State. Commun. 2015, 220, 36-38. [CrossRef]

58. Maple, M.B.; Wittig, J.; Kim, K.S. Pressure-Induced Magnetic-Nonmagnetic Transition of Ce Impurities in La. Phys. Rev. Lett. 1969, 23, 1375. [CrossRef]

59. Hosono, H.; Mishima, Y.; Takezoe, H.; MacKenzie, K.J.D. Nanomaterials: Research Towards Applications; Elsevier Science: Amsterdam, The Netherlands, 2006.

60. Tsuji, Y.; Dasari, P.L.V.K.; Elatresh, S.F.; Hoffmann, R.; Ashcroft, N.W. Structural Diversity and Electron Confinement in Li ${ }_{4}$ N; the Potential for 0-D, 2-D and 3-D Electrides. J. Am. Chem. Soc. 2016, 138, 14108. [CrossRef]

61. Miao, M.-S.; Hoffmann, R. High Pressure Electrides: A Predictive Chemical and Physical Theory. Acc. Chem. Res. 2014, 47, 1311-1317. [CrossRef]

62. Zhu, Q.; Oganov, A.R.; Lyakhov, A.O. Novel stable compounds in the Mg-O system under high pressure. Phys. Chem. Chem. Phys. 2013, 15, 7696. [CrossRef] 